\title{
Pengelompokan Desa Menggunakan K-Means untuk Penyelenggaraan Penanggulangan Bencana Banjir
}

\author{
Shelladita Fitriyani Susilo ${ }^{1}$, Asep Jamaludin ${ }^{2}$, Intan Purnamasari ${ }^{3}$ \\ Universitas Singaperbangsa Karawang \\ e-mail: ${ }^{1}$ shelladita.16207@ student.unsika.ac.id, ${ }^{2}$ asep.jamaludin@ @staff.unsika.ac.id, \\ 3intan.purnamasari@staff.unsika.ac.id
}

Diterima: 25 Juni 2020; Direvisi: 08 September 2020; Disetujui: 25 September 2020

\begin{abstract}
Abstrak
Penyelenggaraan penanggulangan bencana merupakan suatu agenda kewajiban lembaga yang dinamakan BPBD. Perencanaan yang tidak terstruktur menyebabkan penentuan komponen didalamnya menjadi kurang optimal, seperti tempat, sumber daya manusia, transportasi. Penentuan tempat menjadi poin utama yang dapat mempengaruhi komponen lain dalam perencanaan. Ketersediaan data mengenai tempat berupa rekap desa rawan bencana dimiliki oleh bidang I Kesiapsiagaan Bencana. Dari rekap data kejadian dan profil desa dilakukan pengelompokan yang bertujuan untuk menemukan karakteristik yang dapat membantu dalam penentuan tempat kegiatan. Metode K-Means dipilih untuk memetakan desa sesuai karakteristik dengan jumlah cluster sesuai jumlah optimal yang lebih baik antara metode elbow dan silhouette. Dihasilkan clustering optimal dengan jumlah cluster 7 hasil penentuan nilai $k$ dari metode elbow. Dengan ukuran pengelompokan Cluster $1=1$ desa, Cluster $2=2$ desa, Cluster $3=19$ desa, Cluster $4=4$ desa, Cluster $5=5$ desa, Cluster $6=1$ desa, Cluster $7=1$ desa .
\end{abstract}

Kata kunci: Clustering, Elbow, K-Means, Silhouette

\begin{abstract}
Disaster management is an institutional obligation agenda called BPBD. Unstructured planning causes the determination of components in it to be less than optimal, such as place, human resources, transportation. Determination of place is the main point that can affect other components in planning. The availability of data on places in the form of recapitalization of disaster-prone villages is owned by the Disaster Preparedness I field. The recapitulation of village events and profiles is grouped to find characteristics that can help determine the location of activities. The K-Means method is used to map villages according to characteristics with the number of clusters according to the optimal number that is better between the elbow and silhouette methods. Optimal clustering is produced with the number of clusters 7 results of determining the value of $k$ from the elbow method. The grouping size Cluster $1=1$ village, Cluster $2=2$ villages, Cluster $3=19$ villages, Cluster $4=4$ villages, Cluster $5=5$ villages, Cluster $6=$ 1 village, Cluster $7=1$ village.
\end{abstract}

Keywords: Clustering, Elbow, K-Means, Silhouette

\section{PENDAHULUAN}

Banjir di kabupaten Tegal merupakan bencana alam yang sering terjadi pada bulan awal tahun. Pada Januari 2020 telah tercatat laporan kejadian banjir yang melanda 21 desa di beberapa kecamatan. Berdasar pada UU Nomor 24 Tahun 2007 tentang Penanggulangan Bencana yang 
menjelaskan banjir merupakan bencana yang ditanggulangi oleh BPBD. Dalam penanggulangan, BPBD kabupaten Tegal melakukan kegiatan sosialisasi, penyiapan daerah tanggap bencana, dan edukasi terkait pencegahan atau pemantauan langsung. Namun kegiatan seringkali diputuskan secara mendadak. Kurangnya persiapan dalam penentuan tempat dapat mengulur waktu, karena perhatian terhadap ketersediaan sumber daya manusia serta transportasi dilakukan secara mendadak pula. Pemilihan Kegiatan pun sering menjadi kendala karena acuan berpusat pada anggaran. Desa rawan bencana banjir menjadi prioritas BPBD dalam menentukan tempat sehingga digunakan data desa rawan bencana untuk memilah desa sesuai karakteristiknya. Dengan pemilahan desa tentu dapat menentukan kegiatan penyelenggaraan penanggulangan bencana banjir sesuai dengan data desa dan anggaran yang diberikan.

Penambangan data untuk mengelompokan atau memilah desa telah dilakukan sebelumnya dengan menghasilkan kelompok desa berdasar provinsi melalui jumlah pengguna dan sumber listrik [1]. Penambangan data yang digunakan untuk membagi data menjadi suatu kelompok yang homogen ialah clustering [2]. K-Means menjadi salah satu algoritme pengelompokan dalam menghasilkan rekomendasi pekerjaan dengan mengelompokkan data penduduk metode ini memiliki nilai akurasi yang dikategorikan cukup [3].

\section{METODE PENELITIAN}

\subsection{Dataset}

Data berhasil dikumpulkan pada tahapan pemahaman data setelah ditentukan latar belakang dan tujuan penelitian pada tahapan pemahaman bisnis. Data yang digunakan merupakan data sekunder karena melalui wawancara, studi pustaka dan jelajah internet, yaitu dari laporan harian kejadian bencana banjir, web resmi acuan BPBD seperti bnpb.cloud dan prodeskel.binpemdes.kemendagri.go.id. Data desa rawan bencana kabupaten Tegal yang dikumpulkan berjumlah 74 desa dengan 20 atribut dengan beberapa data yang dilihat pada Gambar 1.

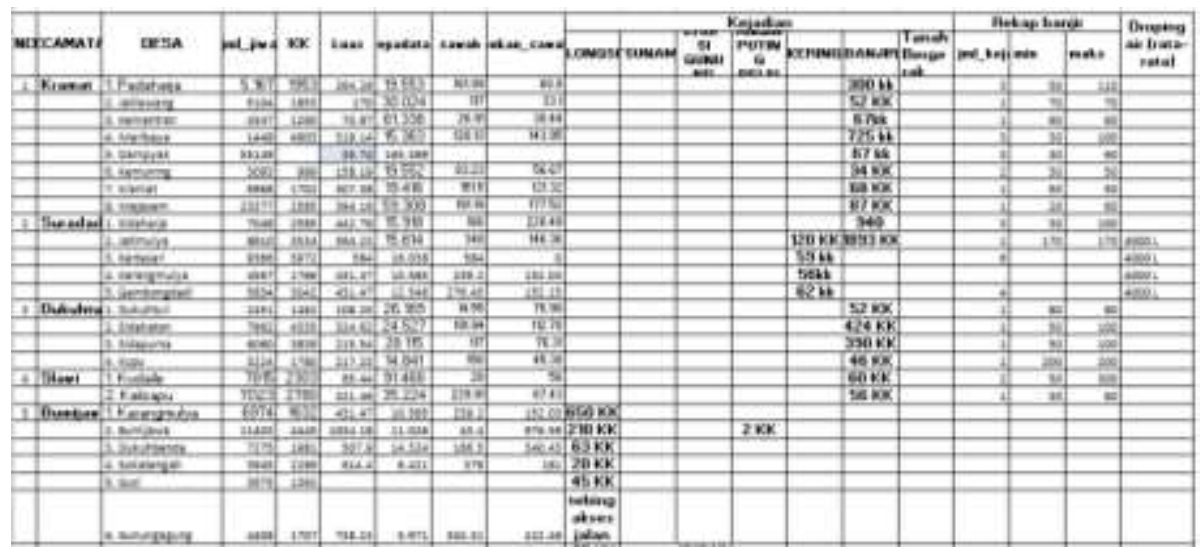

Gambar 1. Rekap Laporan Kejadian Daerah rawan bencana

Berdasarkan acuan awal BPBD, data yang dipilih ialah 33 desa rawan bencana banjir dan 8 atribut yang sering digunakan sebagai keterangan saat terjadi bencana banjir. Antara lain KK, Kepadatan, Sawah, Bukan sawah, Banjir, jml_kejadian, min, dan maks. Pembentukan dataset berkualitas dilanjutkan pada tahapan persiapan dengan melakukan imputasi untuk mengatasi missing value. Imputasi menggunakan mean, karena metode tersebut metode imputasi terbaik setelah 1-NN [4]. Menentukan nilai mean untuk imputasi pada data desa rawan banjir menggunakan formula sebagai berikut [5] :

Mean $=\frac{\text { Jumlah data }}{\text { banyak data }}$ 
Tabel 1. Hasil imputasi menggunakan Mean.

\begin{tabular}{llll}
\hline \multicolumn{1}{r}{ Atribut } & \multicolumn{1}{c}{ Jumlah data } & \multicolumn{1}{c}{ Banyak data } & Mean (Imputasi) \\
\hline KK & 6891 & 33 & 67 \\
Kepadatan & 978.03 & 33 & 30.564 \\
Sawah & 188404 & 33 & 5887.612 \\
Bukan Sawah & 40515 & 33 & 1266.104 \\
\hline
\end{tabular}

Penggunaan persamaan (1) yaitu mean untuk penanganan missing value pada data desa Dampyak, sehingga menghasilkan imputasi seperti dalam Tabel 1. Penanganan selanjutnya yaitu contruct data atau transformasi data. Penanganan tersebut dilakukan untuk mengubah data ke dalam bentuk lain sesuai kebutuhan. Value pada penelitian ini memiliki bentuk data yang besar sehingga perlu melakukan transformasi ke bentuk yang lebih kecil menggunakan transformasi nilai kedalam bentuk $z$-score [6]. Tabel 2 menjelaskan contoh proses transformasi pada salah satu record data pertama menggunakan persamaan (2).

$z=\frac{x-\bar{x}}{s}$

Dimana :

$x:$ data

$\bar{x}:$ rata-rata data

$s:$ standart deviasi

Tabel 2. Contoh transformasi data kedalam bentuk z-score.

\begin{tabular}{llrrrl}
\hline \multicolumn{1}{c}{ Atribut } & \multicolumn{1}{c}{$\boldsymbol{x}$} & $\overline{\boldsymbol{x}}$ & $\boldsymbol{x}$ - $\overline{\boldsymbol{x}}$ & $\boldsymbol{s}$ & \multicolumn{1}{c}{$\boldsymbol{z}$-score } \\
\hline KK & 300 & 210.85 & 89.152 & 359.71 & 0.247841592 \\
Kepadatan & 19.553 & 30.564 & -11.011 & 25.861 & -0.42576205 \\
Sawah & 161.99 & 5887.6 & -5725.6 & 24627 & -0.2325 \\
Bukan Sawah & 68.9 & 1266.1 & -1197.2 & 5769.4 & -0.207508675 \\
Jml kejadian & 3 & 1.6667 & 1.3333 & 1.0918 & 1.2212 \\
min & 50 & 66.364 & -16.364 & 50.741 & -0.3225 \\
maks & 110 & 102.42 & 7.5758 & 56.624 & 0.1338 \\
\hline
\end{tabular}

\subsection{Algoritme $K$-Means}

Pada tahapan pemodelan dipilih teknik clustering dalam data mining guna tercapainya hasil sesuai perencanaan. Dalam setiap kelompok memiliki karakter yang sama namun antar kelompok diciptakan tingkat variasi yang kecil, sehingga memberikan karakteristik yang berbeda [7]. Pengelompokan menggunakan algoritme $K$-Means, sehingga berikut proses pengolahan dataset yang telah dipersiapkan sebelumnya :

1. Menentukan jumlah cluster (k)

2. Menentukan $\mathrm{k}$ yang menjadi titik pusat cluster (centeroid) secara acak untuk awal perhitungan, selanjutnya akan ditentukan centeroid cluster untuk iterasi berikutnya menggunakan persamaan (3).

$v=\frac{\sum_{i=1}^{n} X i}{n} ; i-1,2,3 \ldots \ldots n$

Dengan:

$v$ : titik pusat kelompok

$x i:$ objek data $\mathrm{ke}=\mathrm{i}$

$n:$ jumlah objek yang menjadi anggota cluster 
3. Menghitung jarak setiap objek data ke setiap centeroid yang telah ditentukan menggunakan Euclidean distance [7] pada persamaan (4). Tempatkan setiap objek sesuai dengan titik pusat cluster terdekat.

$D\left(x_{2}, x_{1}\right)=\left\|x_{2}, x_{1}\right\|_{2}=\sqrt{\sum_{j=1}^{p}\left(x_{2 j}-x_{1 j}\right)^{2}}$

Dengan :

$D$ : jarak kuadrat Euclidean antara objek ke $x_{2}$ dan $x_{1}$

$P$ : jumlah variabel cluster

$X_{2 j}$ : data ke-2 pada variabel ke- $j$

$X_{l_{j}}$ : data ke-1 pada variabel ke-j

4. Melakukan iterasi untuk menentukan titik pusat cluster baru

5. Ulangi Langkah ke-3 hingga titik pusat cluster pada titik yang sama

\subsection{Metode Elbow}

Tahapan pertama dalam algoritme $K$-Means yaitu menentukan nilai k [7]. Tahapan pemodelan dalam penelitian ini juga menentukan nilai $\mathrm{k}$ optimal berdasarkan pada hasil perbandingan penerapan metode elbow dan silhouette. Titik siku yang terbentuk dari hasil membandingkan nilai persen dari setiap jumlah cluster adalah cara metode elbow bekerja [7]. Perbandingan didapatkan dengan nilai SSE (Sum of Square Error) setiap kelompok. Penghitungan nilai SSE pada $K$-Means [8] dirumuskan pada persamaan (5).

$S S E=\sum_{K=1}^{K} \sum_{x_{i} \in S_{K}}\left\|X_{i}-C_{k}\right\|_{2}$

Dengan $K$ merupakan banyak cluster yang dipilih, $X_{i}$ merupakan jumlah objek, dan $C_{k}$ merupakan jumlah anggota pada cluster ke-k. Pada [7] Semakin kecil nilai SSE semakin besar nilai cluster, sehingga akan terbentuk siku saat terjadi penurunan drastic seperti pada Gambar 2. <spasi>

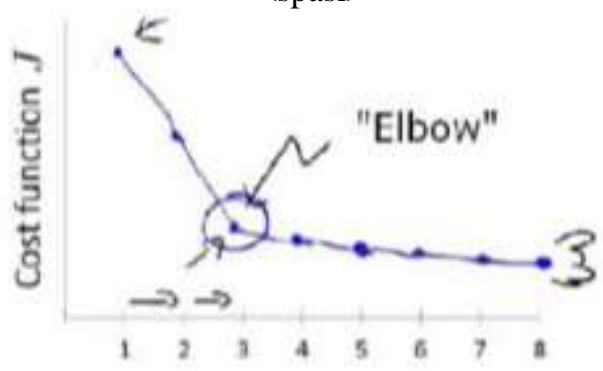

Gambar 2. Grafik Elbow. Sumber : Eka Merliana et al., 2015 dalam [7]

\subsection{Metode Silhouette}

Cara menentukan cluster yang baik dengan metode ini yaitu dengan nilai rata-rata dari perhitungan silhouette yang tinggi [9]. Nilai silhouette ditentukan dengan perhitungan sebagai berikut [10]:

1. Menghitung average distance objek ke-o dengan semua objek dalam satu cluster menggunakan persamaan (6).

$a(o)=\frac{\sum o^{\prime} \in C_{k}, o \neq o^{\prime} \operatorname{dist}\left(o, o^{\prime}\right)}{\left|C_{i}-1\right|}$

Dimana:

$o \quad$ : Objek ke-o pada cluster $i$

$o^{\prime}$ : Objek lain pada cluster $i$ selain objek ke-o

$C_{i}:$ Cluster $i$

$\left|C_{i}\right|$ : jumlah objek pada cluster $i$

dist (o.o') : jarak data $o$ dengan data $o$ '

2. Menghitung average distance objek ke-o dengan semua objek dari cluster lain menggunakan persamaan (7) kemudian pilih dengan nilai terendah. 
$b(i)={ }_{C_{j}: 1 \leq j \leq k, j \neq i}^{\min }\left\{\frac{\sum o^{\prime} \in C_{j} \operatorname{dist}\left(o, o^{\prime}\right)}{\left|C_{j}-1\right|}\right\}$

Dimana:

$o \quad$ : Objek ke-o pada cluster $j$

$o^{\prime}$ : Objek lain pada cluster $j$ selain objek ke-o

$C_{j}:$ Cluster $j$

$\left|C_{j}\right|$ : jumlah objek pada cluster $j$

$\operatorname{dist}\left(o . o^{\prime}\right)$ : jarak data $o$ dengan data $o$ '

3. Pada objek $k$ memiliki nilai silhouette coefficient dengan memasukkan nilai $a(o)$ dan $b(o)$ pada persamaan (8) :

$S_{i}=\frac{\left(b_{i}-a_{i}\right)}{\max \left(a_{i}, b_{i}\right)}$

Dimana:

$S_{i}$ : Nilai Silhouette coefficient pada obkej ke $i$

$a_{i}$ : Nilai $a(o)$ pada objek ke $i$

$b_{i}$ : Nilai $b(o)$ pada objek ke $i$

\subsection{Parameter cluster optimal}

Penilaian ideal cluster jika $V$ memiliki nilai yang minimum, yaitu dengan penghitungan $V$ [6] pada persamaan (9). Ideal cluster dapat dilihat sesuai keterangan pada Tabel 3, yaitu cluster yang memiliki variance within minimum dan variance between maksimum.

$V=\frac{\text { Variance within }}{\text { Variance between }} \times 100 \%$

Tabel 3. Parameter penentuan hasil clustering k optimal

\begin{tabular}{ll}
\hline \multicolumn{1}{c}{ Parameter } & \multicolumn{1}{c}{ Keterangan } \\
\hline Variance withinss & $\begin{array}{l}\text { Semakin kecil variance withinss semakin baik } \\
\text { pengelompokan } \\
\text { Variance Beetweenss }\end{array}$ \\
& $\begin{array}{l}\text { Semakin besar variance betweenss semakin baik } \\
\text { pengelompokan }\end{array}$ \\
\hline
\end{tabular}

Between sum of square adalah Jarak antar cluster dan Within Variance sum of square adalah Jarak antara anggota dalam cluster [11]. Diperlukan nilai variance within yang minimun dan variance between maksimum untuk menentukan cluster ideal [6] yang bisa dihitung menggunakan persamaan (10), (11), dan (12). Berikut formula perhitungan variance between dan variance within menurut Keppel \& Wickens (2004) dalam [12]:

Variance $=$ Mean Asuqres $(M S)=\frac{\text { sum of square }}{\text { derajat bebas }(d f)}$

Variance between $=\frac{\text { sum of square between }}{\text { banyaknya kelompok-1 }}$

Variance within $=\frac{\text { sum of square within }}{\sum \text { (anggota per kelompok-1) }}$

\section{HASIL DAN PEMBAHASAN}

Sesuai dengan alur tahapan-tahapan yang dimiliki oleh CRISP-DM, penelitian ini menghasilkan kelompok desa dengan pembagian kelompok yang ideal. Data dilakukan pemilihan hingga menjadi dataset berkualitas. Kemudian diterapkan metode $K$-Means dengan memaksimalkan tahapan pemilihan k optimal. Perbandingan metode elbow dan Silhouette untuk 
menentukan nilai k optimal. Pemodelan dilakukan dengan menggunakan software R. Penerapan pada $\mathrm{R}$ menghasilkan beberapa komponen dengan keterangan yang tertera pada Tabel 4. Indikator yang menjadi perbandingan hasil clustering ialah nilai variance between dan variance withinss.

Tabel 4. Hasil penerapan $K$-Means pada $R$ sumber [13]

\begin{tabular}{ll}
\hline \multicolumn{1}{c}{ Komponen } & \multicolumn{1}{c}{ Keterangan } \\
\hline cluster & Hasil analisis pengelompokan dari 1:k \\
center & Matriks titik pusat cluster \\
totss & Jumlah keseluruhan deviasi kuadrat \\
Withinss & Vektor dari within-cluster sum of square, suato objek dalam cluster \\
Tot.withinss & Total within-cluster sum of square \\
betweenss & Between-cluster sum of squares, atau totss-tot.withinss. \\
Size & Jumlah anggota per cluster \\
Iter & Jumlah iterasi \\
Ifault & Jumlah masalah pada algoritma (untuk ahli) \\
\hline
\end{tabular}

\subsection{Penentuan nilai k dengan metode elbow}

Hasil nilai K optimal dengan metode elbow pada Gambar 3 ditentukan oleh garis yang mulai melandai setelah curam hingga membentuk siku pada titik k optimal [7]. Pada Gambar 3 garis mulai melandai setelah titik 7 sehingga titik k optimal menggunakan metode elbow ialah 7.

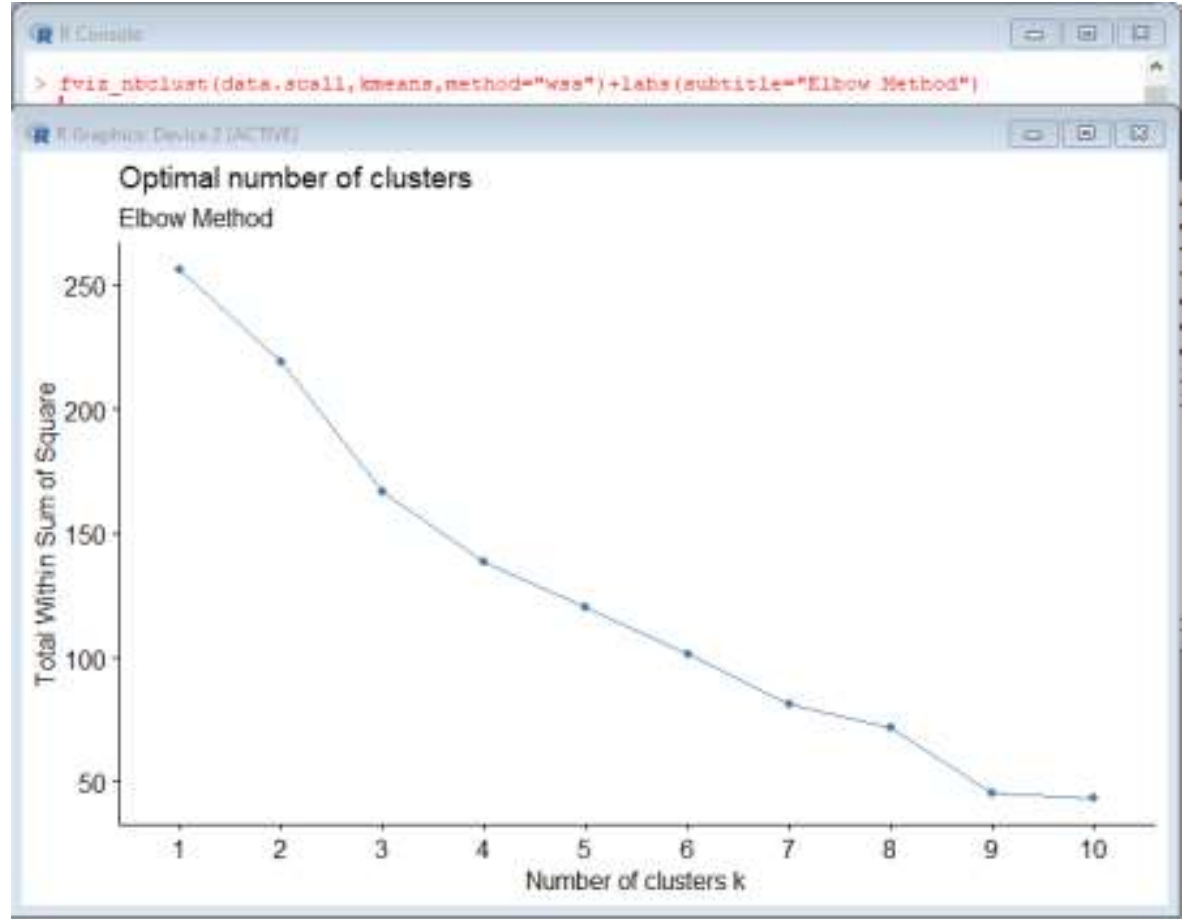

Gambar 3. Hasil nilai k metode elbow

Berdasarkan perhitungan $K$-Means pada R, perhitungan berhenti pada iterasi ke-4 dengan jumlah data per cluster yang di vektorkan pada Gambar 4 dengan komponen iter dan size. Iterasi tidak dilanjutkan karena algoritme telah mencapai kondisi dimana alokasi kembali pada titik data sebelumnya dan titik pusat cluster tetap sama [14]. Gambar 4 juga menunjukan vektor Within sum of square, Total Within sum of square dan Between sum of square yang dihasilkan dengan nilai optimal 7 pada komponen withinss, Tot.withinss, dan Betweenss. 


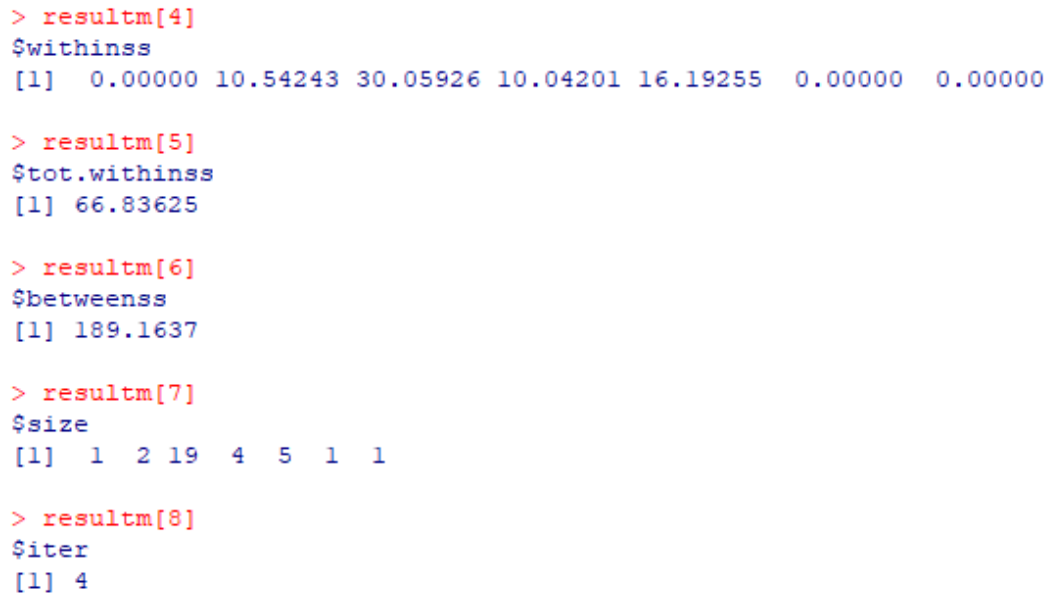

Gambar 4. Komponen hasil K-Means dengan metode elbow

Jumlah deviasi kuadrat (sum of square) yang dihasilkan dapat digunakan untuk menentukan varians (variance) yang dibagi dengan derajat bebas (degrees offredom atau df) [12]. Nilai variance dari $\mathrm{k}=7$ yaitu sebagai berikut :

Variance between $=\frac{189.1637}{7-1}=27.0233857$

Variance within $=\frac{66.83625}{((1-1)+(2-1)+(19-1)+(4-1)+(5-1)+(1-1)+(1-1))}=2.570625$

Penerapan K-Means menggunakan k= 7 yang menghasilkan size atau jumlah anggota per cluster berurutan yaitu 1, 2, 19, 4, 5, 1, 1 yang divisualisasikan pada Gambar 5

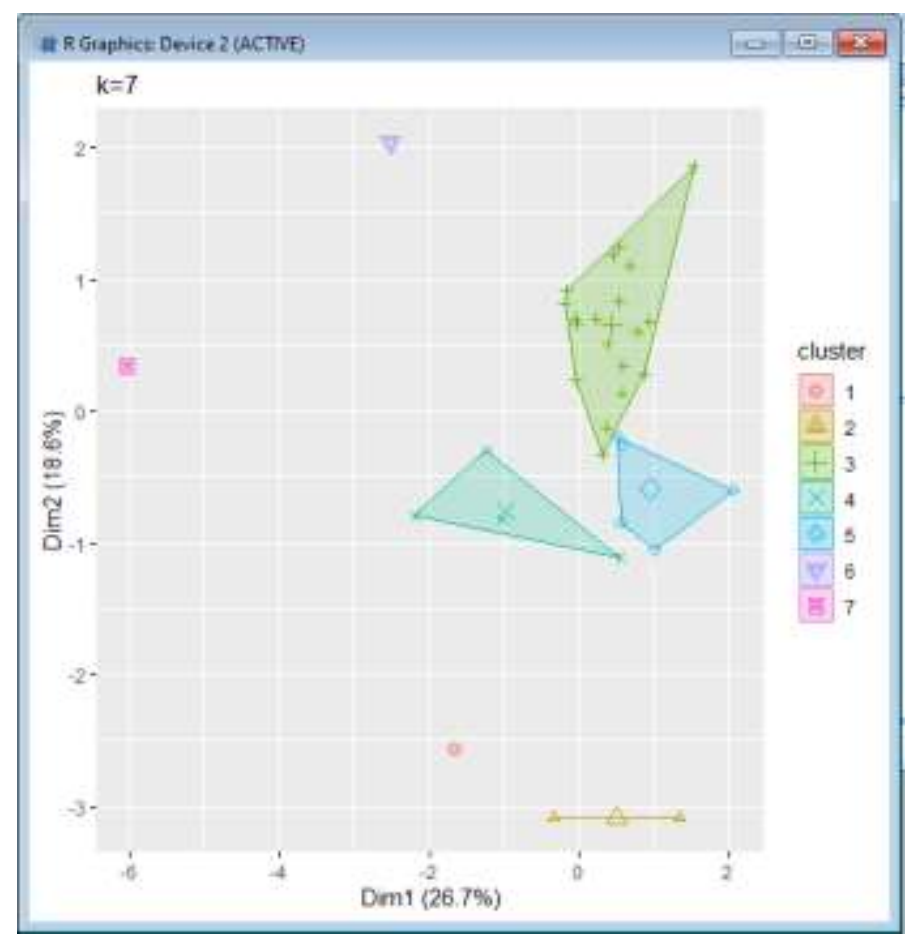

Gambar 5. Pemetaan menggunakan nilai k metode elbow 
3.2. Penentuan nilai k dengan metode silhouette

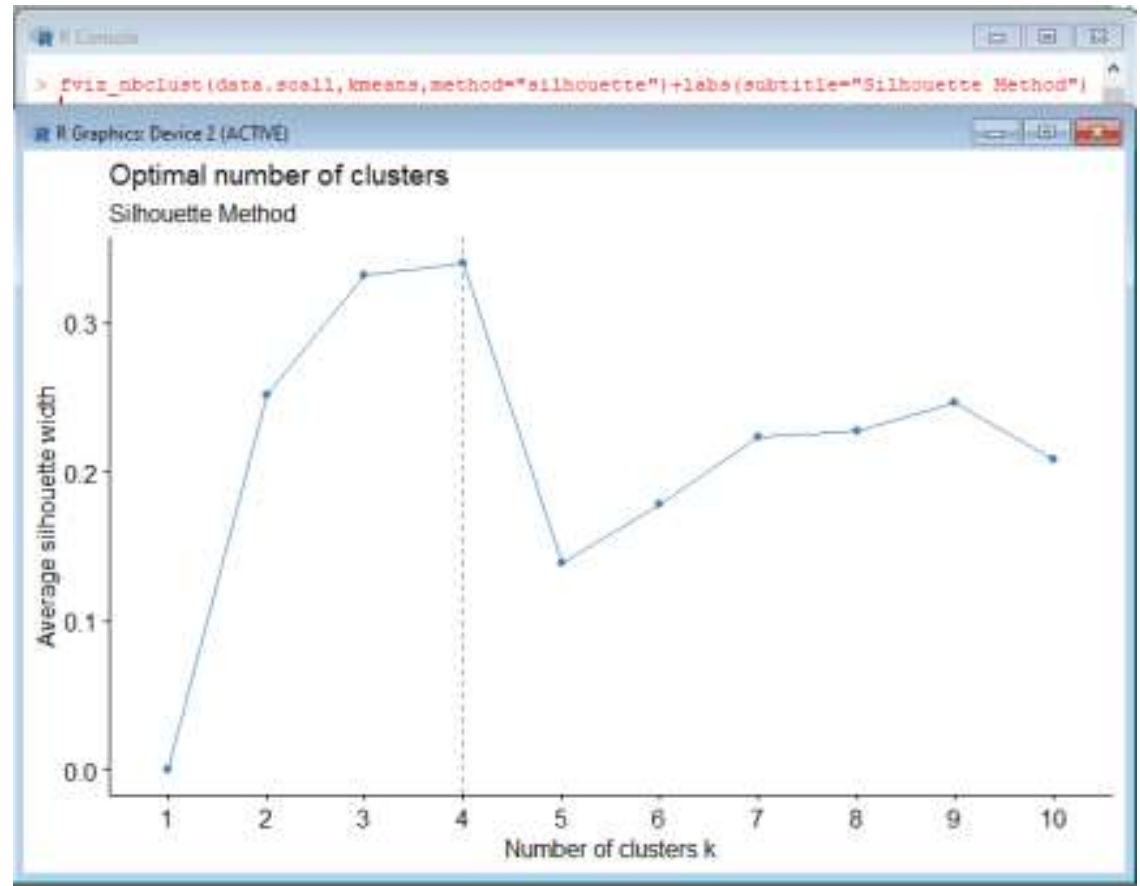

Gambar 6. hasil nilai k metode silhouette

Sesuai dengan garis penunjuk yang memotong grafik pada Gambar 6, menunjukkan bahwa nilai $\mathrm{k}$ optimal penerapan metode silhouette ialah 4 . Proses clustering dengan nilai $\mathrm{k}=4$ menghasilkan tot.withinss (Total withinss sum of square) sebesar 136.384 dan Betweenss (betweens sum of square) sebesar 119.616. Komponen hasil dari penerapan K-Means lainnya menggunakan $\mathrm{k}=4$ dapat dilihat pada Gambar 7, seperti komponen size yang merupakan jumlah anggota dari 4 cluster secara berturut-turut, vektor withinss dan jumlah iterasi terakhir dalam mengalokasikan objek dengan perhitungan jarak.

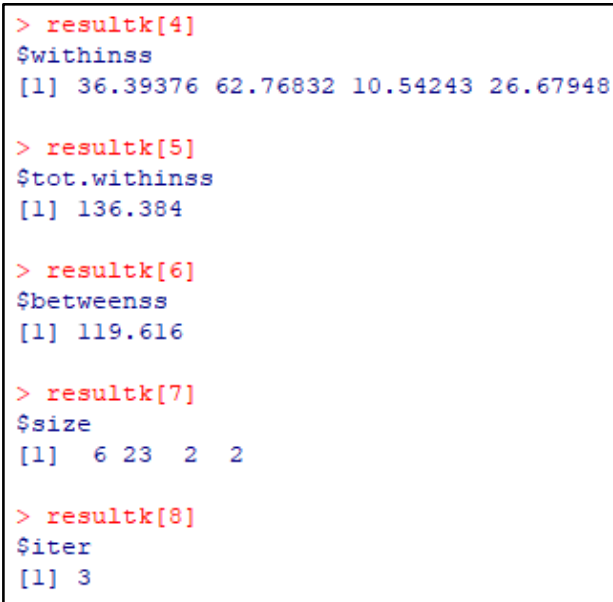

Gambar 7. Komponen hasil K-Means dengan metode silhouette

Withinss sum of square dan between sum of square yang dihasilkan kemudian dilakukan perhitungan untuk menentukan variance atau jarak objek [12]. Variance between dan Variance within yang dihasilkan dari 4 cluster menggunakan algoritme $K$-Means ialah sebagai berikut: 
Variance between $=\frac{119.616}{4-1}=39.872$

Variance within $=\frac{136.384}{((6-1)+(23-1)+(2-1)+(2-1))}=4.70289655$

Size atau jumlah anggota per cluster berurutan hasil penerapan $K$-Means menggunakan nilai $\mathrm{k} 4$ yaitu 1, 2, 19, 4, 5, 1, 1 divisualisasikan dalam bentuk pemetaan pada Gambar 8 .

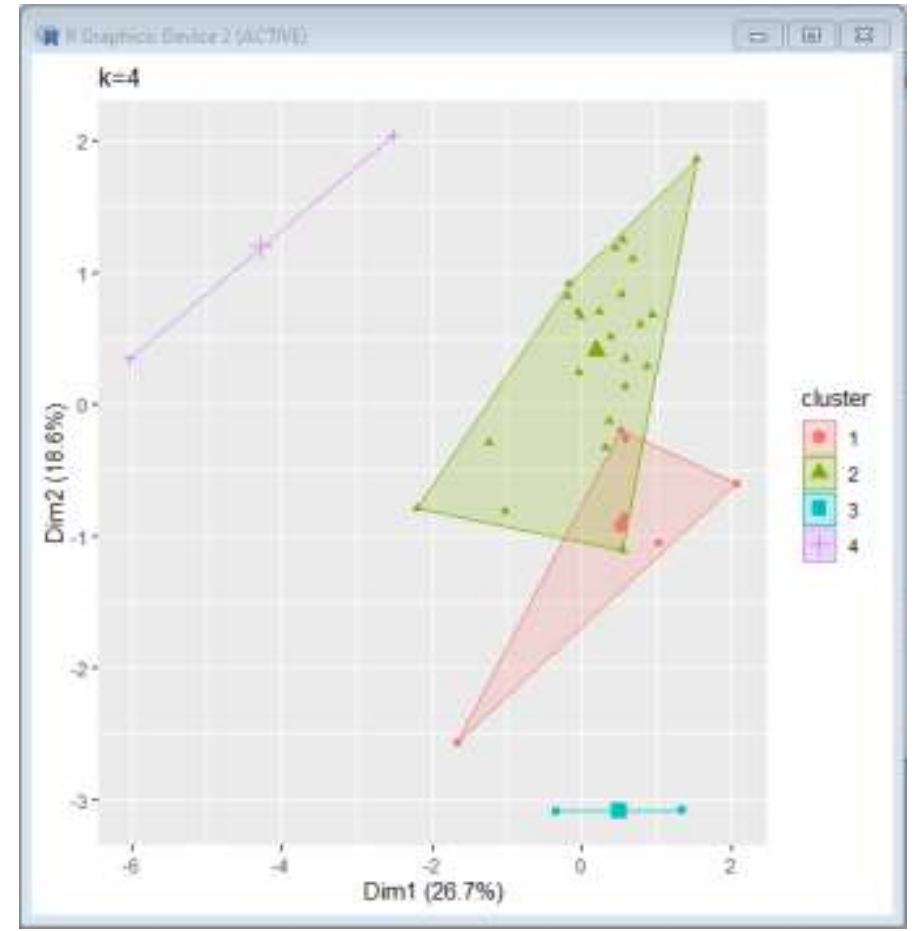

Gambar 8. Pemetaan menggunakan nilai k metode silhouette

\subsection{Pembahasan}

Pada Tabel 5 memperlihatkan rekap hasil perhitungan variance penerapan 2 metode penentuan nilai k, yaitu metode elbow dan silhouette.

Tabel 5. Perbandingan nilai variance

\begin{tabular}{lcll}
\hline \multicolumn{1}{c}{ Metode } & Cluster & Variance Within & Variance Between \\
\hline Elbow & 7 & 2.570625 & 27.0233857 \\
Silhouette & 4 & 4.70289655 & 39.872 \\
\hline
\end{tabular}

Dari penentuan nilai $\mathrm{k}$ optimal dengan kedua metode dihasilkan variance within dan variance between dari metode elbow dan metode silhouette yang akan digunakan untuk mengevaluasi pengelompokan teroptimal, sebagai berikut :

Metode Elbow

$V_{\text {Elbow }}=\frac{2.570625}{27.0233857} \times 100 \%=9.51259412 \sim 9.5 \%$

Metode Silhouette

$V_{\text {Silhouette }}=\frac{4.70289655}{39.872} \times 100 \%=11.79498532 \sim 11.8 \%$

Dari perhitungan $V$ masing-masing metode dihasilkan nilai $V$ minimum oleh pengelompokan $K$-Means dengan $\mathrm{k}=7$, yaitu penentuan nilai $\mathrm{k}$ optimal menggunakan metode elbow. Cluster yang terbentuk memiliki karakteristik yang berbeda-beda sehingga dapat dijadikan 
acuan dalam menentukan kegiatan yang diinginkan sesuai kebutuhan desa dalam cluster. Rincian karakteristik setiap cluster dapat dilihat melalui kolom keterangan pada tabel 6.

Tabel 6. Hasil clustering

\begin{tabular}{|c|c|c|}
\hline No & Desa & Keterangan \\
\hline 1 & Jatimulya & $\begin{array}{l}\text { Memiliki jumlah KK yang relatif tinggi, KK } \\
\text { yang terdampak tinggi, jarang terjadi banjir } \\
\text { namun genangan yang terjadi dapat tinggi }\end{array}$ \\
\hline 2 & Kudaile, Tembok Banjaran & $\begin{array}{l}\text { Memiliki luas lahan yang rendah, kepadatan } \\
\text { tinggi dan paling sering terjadi banjir }\end{array}$ \\
\hline 3 & $\begin{array}{l}\text { Padaharja, Jatilawang, Kemantran, } \\
\text { Kemuning, Kramat, Dampyak, } \\
\text { Dukuhturi, Kalisapu, Pecabean, } \\
\text { Pedeslohor, Bersole, Tembok Lor, } \\
\text { kaliwadas, Prupuk Selatan, Wotgalih, } \\
\text { Blubuk, Sokareja, Banjaragung, } \\
\text { Sidamulya }\end{array}$ & $\begin{array}{l}\text { Memiliki kepadatan sedang, lahan sedang, } \\
\text { kadang terjadi dengan genangan dari rendah } \\
\text { menuju sedang ke tinggi. }\end{array}$ \\
\hline 4 & $\begin{array}{l}\text { Kupu, Lemah Duwur, Pagiyanten, } \\
\text { Pesarean }\end{array}$ & $\begin{array}{l}\text { Memiliki kepadatan dan genangan yang relatif } \\
\text { tinggi namun jarang terjadi banjir }\end{array}$ \\
\hline 5 & $\begin{array}{l}\text { Maribaya, Mejasem, } \\
\text { Sidakaton, Sidapurna }\end{array}$ & $\begin{array}{l}\text { Memiliki lahan sawah dan bukan sawah yang } \\
\text { hampir seimbang, jumlah penduduk yang paling } \\
\text { tinggi dan kk yang terdampak relatif tinggi }\end{array}$ \\
\hline 6 & Semedo & Memiliki kepadatan dan jumlah kk paling rendah \\
\hline
\end{tabular}

Hasil withinss (within sum of square) dan Betweenss (between sum of square) dari penerapan $K$-Means menggunakan R selain menujukkan jarak antar anggota dan antar cluster [11], dapat juga dilakukan perhitungan manual untuk menghasilkan variance within dan variance between. Sesuai perbandingan variance within dan variance between dihasilkan nilai $V$ yang menunjukan bahwa dengan metode elbow dihasilkan jumlah cluster yang ideal menggunakan algoritme $K$-means. Nilai $V$ dari clustering $K$-Means menggunakan metode elbow lebih minimum dibandingkan penentuan $\mathrm{k}$ optimal menggunakan metode silhouette sesuai dengan definisi dari [6] mengenai cluster ideal. Penentuan nilai k optimal menggunakan elbow memberikan hasil 7 cluster dengan karakteristik yang berbeda antar kelompok namun sama antar objek dalam cluster. Setiap cluster memiliki karakteristik sesuai dengan faktor pemicu banjir pada [15], seperti cluster 2 yang memiliki kepadatan penduduk yang tinggi sehingga akan sering terjadi banjir dan cluster 7 yang kurang memiliki lahan resapan hingga saat curah hujan tinggi air yang akan tergenang juga tinggi.

\section{KESIMPULAN}

Dari penerapan $K$-Means pada data rekapan laporan kejadian banjir Bidang I Kesiapsiagaan Bencana BPBD Kabupaten Tegal dan pengujian dalam menentukan nilai k optimal menggunakan metode elbow dan silhouette. Maka diperoleh kesimpulan bahwa hasil perbandingan nilai $V$ menunjukan penerapan metode elbow pada algoritme $K$-Means lebih ideal. Cluster yang terbentuk yaitu, cluster 1 : desa Jatimulya, cluster 2 : desa Kudaile dan Tembok Banjaran, cluster 3 : desa Padaharja, Jatilawang, Kemantran, Kemuning, Kramat, Dampyak, Dukuhturi, Kalisapu, Pecabean, Pedeslohor, Bersole, Tembok Lor, kaliwadas, Prupuk Selatan, Wotgalih, Blubuk, Sokareja, Banjaragung, Sidamulya, cluster 4 : desa Kupu, Lemah Duwur, Pagiyanten, Pesarean, cluster 5 : desa Maribaya, Mejasem, Sidaharja, Sidakaton, Sidapurna, cluster 6: Semedo, dan cluster 7 : Kedungsukun. Nilai tot.withinss sebesar 66.83625 yang lebih kecil dan betweens yang lebih besar yaitu 189.1637 menunjukan jarak dekat antar objek per cluster dan jarak yang jauh antar cluster 


\section{SARAN}

Saran yang dapat diperhatikan untuk penelitian selanjutnya ialah memaksimalkan pengelompokan dengan tambahan data yang berpengaruh langsung pada bencana banjir, seperti mengenai curah hujan, DAS dan pemukiman sekitar bantaran sungai. Saran berikutnya untuk pengembangan lebih baik perlu dilakukan penerapan metode lain untuk pengelompokan atau untuk memaksimalkan setiap tahapan pengelompokan. Serta melakukan perbandingan untuk menentukan pengelompokan yang lebih spesifik dalam menghasilkan karakteristik.

\section{DAFTAR PUSTAKA}

[1] M. G. Sadewo, A. P. Windarto and D. Hartama, 2019, Algoritma K-Means Dalam Mengelompokkan Desa/Kelurahan Menurut Keberadaan Keluarga Pengguna Listrik dan Sumber Penerangan Jalan Utama Berdasarkan Provinsi, Seminar nasional teknologi Komputer \& Sains (SAINTEKS), pp. 754-761, Januari.

[2] G. Shmueli, P. C. Bruce, I. Yahav, N. R. Patel and K. C. Lichtendahl Jr., 2018, Data Mining for Bussiness Analytics Concepts, Techniques, and Applications in R, John Wiley \& Sons, Inc.

[3] L. Listiani, Y. H. Agustin and M. Z. Ramdhani, 2019, Implementasi Algoritma K-Means Cluster Untuk Rekomendasi Pekerjaan Berdasarkan Pengelompokkan Data Penduduk, In Sensitif 2019, Tasikmalaya.

[4] T. Ariwibowo, 2019, Perbandingan Metode Imputasi Mean, Median, Modus, Dan 1-Nn Pada Hasil Klasifikasi K-Nearest Neigbour (K-Nn) Studi Kasus : Klasifikasi Penyakit Jantung Koroner, Universitas Pembangunan Nasional Veteran.

[5] H. Satriawan, 2018, Problematika Pembelajaran Matematika Pada Materi Statistika Smp Kelas IX, Jurnal Elektronik Pembelajaran Matematika, vol. 5, pp. 278-285, Oktober.

[6] N. Asiska, N. Satyahadewi and H. Perdana, 2019, Pencarian Cluster Optimum Pada Single Linkage, Complete Linkage Dan Average Linkage, Buletin Ilmiah Math, Stat, dan Terapannya (Bimaster), vol. 8, pp. 393-398.

[7] R. I. Fajriah, H. Sutisna and B. K. Simpony, 2019, Perbandingan Distance Space Manhattan Dengan Euclidean Pada K-Means Clustering Dalam Menentukan Promosi, IJCIT (Indonesian Journal on Computer and Information Technology), vol. 4, pp. 36-49, Mei.

[8] A. F. Febrianti, A. H. Cabral and G. Anuraga, 2018, K-Means Clustering Dengan Metode Elbow Untuk Pengelompokan Kabupaten Dan Kota Di Jawa Timur Berdasarkan Indikator Kemiskinan, in SNHRP-1.

[9] C. D. Rumiati and I. Budi, 2017, Segmentasi Pelanggan Pada Customer Relationship Management Di Perusahaan Ritel: Studi Kasus Pt Gramedia Asri Media, Jurnal Sistem Informasi (Journal of Information Systems), vol. 13, no. 1, pp. 1-10, April.

[10] B. Santoso, I. Cholissodin and B. D. Setiawan, "Optimasi K-Means untuk Clustering Kinerja Akademik Dosen Menggunakan Algoritme Genetika," Jurnal Pengembangan Teknologi Informasi dan Ilmu Komputer, vol. 1, pp. 1652-1659, 2017.

[11] Y. Novianti, 2017, Implementasi K-Means Clustering Algorithm Untuk Analisa Soal Ujian Online Pada Smp Islam Al-Fath Pare, Simki-Techsain, vol. 1.

[12] Kusnendi, 2016, Memahami Analisis Varians.

[13] K-Means Clustering, https://stat.ethz.ch/R-manual/R-patched/library/stats/html/kmeans.html, diakses tgl 20 Februari 2020. 
[14] R. Adrianto and A. Fahmi, 2016, Penerapan Metode Clustering Dengan Algoritma KMeans Untuk Rekomendasi Pemilihan Jalur Peminatan Sesuai Kemampuan Pada Progam Studi Teknik Informatika - S1 Universitas Dian Nuswantoro, pp. 101-116.

[15] E. Yulaelawati, Ph.d and U. Syihab, Ph.d, 2008, Mencerdasi Bencana : banjir, tanah longsor, tsunami, gempa bumi, gunung api, kebakaran, Grasindo. 